\title{
The Effect of Eurasian Orientation on the Relations between Russia and America
}

\author{
Ahmad Jansiz ${ }^{1}$, Mustafa Tarin ${ }^{2} \&$ Samira Talebi ${ }^{2}$ \\ ${ }^{1}$ Political Science, University of Guilan, Rasht, Iran \\ ${ }^{2}$ Independent Researcher on International Relations, Rasht, Iran \\ Correspondence: Ahmad Jansiz, Department of Political Science, Faculty of Humanity, University of Guilan, \\ Rasht, Iran. Tel: 98-912-384-48-35. E-mail: jansiz@guilan.ac.ir.
}

Received: July 19, 2016

doi:10.5539/ach.v8n2p135
Accepted: July 28, 2016

URL: http://dx.doi.org/10.5539/ach.v8n2p135

\begin{abstract}
The international system is an arena for relations and interactions. Sometimes these relations are along with peace and sometimes with conflicts and tensions. Accordingly, countries use certain ideologies and policies that can lead to the promotion or demotion of their position in the international system. The collapse of the Soviet Union was a turning point for the change of the nature of the international system -from bipolar to unipolar- and also Russia's attempt to redefine its lost identity which prepared the ground for the influx of new discussions and approaches in the international arena. Seeking its lost identity, Russia came up with the reality that Atlantic Orientation and following the unipolar system not only did not solve its problems but led to its decline, disappointment and frustration at the internal and international level; therefore, with Putin's accession to power, another major turning point came in Russian foreign policies, which led to the improvement of the economic conditions in Russia following the increase in the oil price and Putin's strategic leadership and management. The policy and approach taken in Russia originated from the self-confidence it had built up. This not only increased Russia's maneuverability at the region but leveled the ground for its confrontation with America and challenging the unipolar system. As a result, adopting the Eurasian Orientation policy since 2000 not only caused Russia's attention to turn to Central Asia countries and Caucasus but has also promoted an aggressive or offensive attitude in the policies taken by this country. Thus, taking an Offensive Realism approach, the present study seeks to find an answer to this question: What is the role and effect of Eurasian Orientation policy on Russia's foreign policies towards America? The data for this study were collected by drawing on dissertations, libraries and research findings and analyzed using a descriptive analytic approach.
\end{abstract}

Keywords: Eurasian Orientation, Russia, America, Foreign policy, international system

\section{Introduction}

After the collapse of the Soviet Union, the international system changed from its bipolar form into a unipolar system and America's hegemony and the Soviet Union broke into several independent countries with their particular foreign policies, but Russia still considered itself as the father and chief of the Caucasus region and Eurasia. Particularly after Putin's accession to power and with the end of Yeltsin's rule, in addition to Putin's progressive policies, the changes in the international system went in this country's favor. In this period of time, Russia made an attempt to build up and bring back its lost reputation in the region and, accordingly, did not spare any effort in redefining its identity. At the same time with the rise of Putin to power, the price of energy resources also increased. The rise in energy prices was followed by the promotion of Russia's self-confidence and an increase in its power. These happenings generated and strengthened the motivation for confronting and taking positions against the United States policies and challenging the unipolar system for Russia and its Moscow's foreign policies changed from 'following' to the 'balance of power' or 'power tranquility' policies. This was followed by taking an offensive attitude by Russia. In the present article, in the first section we will look at the commonalities between Offensive Realism and redefinition of Russian foreign policy in this framework and, in the second part, the reasons and factors related to Eurasian orientation policies and, finally, the role and effect of these two factors (i.e., redefinition of Russian foreign policy and Eurasian orientation policies) on the relations between Moscow and Washington will be analyzed considering Russia's aggressive 
behavior at the time of Putin's rule and its relationship with taking the Eurasian orientation policy by Putin and its role in the relations with America.

\section{Theoretical Background: Offensive Realism}

Offensive Realism is a branch of realism and assumptions such as power, security, government, anarchy and great powers are considered as its major components as in the classic realism. As against other schools of thought in the field of criticizing and examining the international relations and policies, each of which has been introduced with certain well-known characters, this school of thought has been less characterized by the mentioned features. In other words, a very small number of scientists have tried to explain and provide a theoretical framework for Offensive Realism. Complying with the other schools of thought in the international arena, Offensive Realism has based its intellectual foundation on realistic doctrine and assumptions. The followers of this school of thought recognize the governments, based on the realistic frameworks, as the main actors in the international relations arena and believe that it is the great powers that form the international policies and the great power outputs play a determining role and affect the international system (Schwelle, 1996). According to Offensive Realism, anarchy forces the governments to maximize their relative power or influence because, from their perspective, there is a relationship between systemic requirements and following the neo-realists including the defensive and offensive realists, who claim that the world is competitive and uncertain and the structure of the international system has made the policy of power as the dominant political paradigm. This perspective fits the system of benefits and beliefs of the majority military strategists and foreign policy decision makers who are in power in the world today (Baylis \& Smith, 2004, 445).

To ensure their survival, the governments should put keeping or improving their position of power on the agenda in their foreign policies and since power is defined in the final analyses as the ability to declare a war, the governments always put the emphasis on creating and developing their military establishment (Pfaltzgraff and Dougherty, 2004, 445). According to Mearsheimer, one of the most important theoreticians of Offensive Realism, the most fundamental bases of the international system are formed with the performance of the great powers and, to achieve absolute security, the powers think of eliminating the potential threats from other powers that are likely to practice hegemony. Therefore, to talk about issues such as democratic peace and security-building cooperation is only to justify offensive behaviors of the great powers (Salimi, 2005, 34-36). Mearsheimer's theory, i.e., Offensive Realism, puts emphasis on this assumption that basically international policies are an attempt to increase relative power and the governments will not quit their efforts as long as they have not become a hegemonic power. Accordingly to Mearsheimer $(2001,139)$, this behavior originates from the fear of the anarchic situation of the international system and makes desire for survival a requirement and makes the governments follow and show an offensive behavior. And Offensive Realism is based on this very assumption.

In summary, Offensive Realism helps to understand the international policies by explaining the foreign policies and considers achieving absolute security as the most important demand of the great powers, which is achievable only via power and maintaining and practicing hegemony. These powers are the main actors in the international system and try to ensure their survival and increase their power in an anarchic atmosphere. Therefore, they attempt to outperform others in their foreign policy planning.

\section{Eurasian Orientation and Russia's Offensive Policy}

When Putin came to power and after the end of Yeltsin's rule, with the progressive views and policies of Putin, the changes in the international system happened as desired and favored by Russia. In this range of time, Russia sought to restore its lost reputation and preserve and keep its rule and influence over the region. Accordingly, they made every attempt to redefine their identity. Simultaneously the price of energy sources such as oil rose. The increase in energy price was followed by an increase in Russia's self-confidence and power, which provided the necessary motivation for Russia to take positions against the United States and pose a challenge to the unipolar international system and change its policy from 'following' to 'balance of power'. This led Russia to take an offensive approach and strategy and, today, as Russia further follows and advances its policy, its tensions in the region and the international system also increase to the same extent and it becomes more offensive.

By gaining the necessary power and strength, the first ultimatum given to the world by Russia was to challenge the unipolar system imposed by America. Having large energy resources as a source of power, Russia attempted make decisions on the world's especially the European countries' behalf. Based on the Offensive Realism theory, the most important ambitions of any country is to reach absolute security and Russia uses all the necessary and effective tools to achieve this goal. Threatening, stopping the gas exports, posing sanctions and even using weapons by Russia are all evidence for this claim that it resorts to the use of any instrument for 
gaining power and achieving absolute security. Apart from that, America's and NATO's approximation to any of the countries Caucasus region might be a bullet in Russia's heart.

In analyzing and evaluating Russia's foreign policy towards the neighboring countries especially those surviving the collapse of the Soviet Union, there is a belief that Russia considers itself as the big brother in the region and seeks to keep and preserve the union which was dominant during the Soviet period. In other words, it seeks to form the Russian Union once again but this time not with authoritarianism. Under the Eurasian Orientation mask, Russia wants to rule over Asia and Europe and considers any tension or conflict in these areas as a threat to its political position and a threat to its security borders.

Russia considers the presence and challenge of any other power besides the regional countries as a threat to its security and benefits. Therefore, the fight with America and preventing the development of NATO in the region is one of the Eurasian Orientation strategies used by Russia and indicative of its offensive approach which puts a stop to any feeling of insecurity. The collapse of the Soviet Union, in fact, changed the conditions of the international system with America ruling over the world as a hegemony and makes every effort to maintain the status quo. In contrast, Russia still had its old ambition in mind, i.e. the ambition of ruling over the whole world or at least, at the present time, over Europe and Asia, is not happy with the existing situation and can use the domino of attaching the regional countries such as Crimea to Russia to achieve this goal.

As it was previously mentioned, one of the notable assumptions of the Offensive Realism is the persistence in achieving absolute security and, from this perspective, Russia is one of the greatest powers in the production of weapons and missiles and one of the powers that has nuclear power, which is deterrent in nature.

At the same time with the changes in Russia's policies from 'following' to the policy of 'balance of power' and in the attempt to achieve a superior power in the region and after alignment with the hegemony, Russia attempts to change the international system in line with itself by taking the pragmatic policy and behavior. In addition, it tries to maintain its dominance over the independent states of the former Soviet Union. In line with that, one of the most important approaches taken by Russia is attention to Eurasian Orientation. The proponents of this theory want to achieve two goals through creating unions and promoting cooperation at the regional level: on the one hand, improving the regional cooperation leads to the countries' dependence on Russia and in this way it can influence the foreign policy of these countries because the common tradition in these countries is that when they become friends with Russia, they will normally turn away from America.

Becoming more powerful against the other competitors increases the great powers' chances of survival. An everlasting power has an implication that the great powers are looking for opportunities to change the global distribution of power to their advantage. If they have the required capabilities and capacities, then they will make the best of the opportunities. Accordingly, it can be stated that these powers have offensive thoughts in mind from the very beginning. Despite that, a great power not only does not seek to gain more power against the opponents but tries to neutralize their power by resorting to its power. Therefore, a great power will only support the balance of power when the changes are to its advantage and to the opponents' disadvantage and seeks to undermine the balance of power when the changes are not in its favor but against its demands and desire (Mearsheimer, 2004, 3). Based on this belief, similar to other countries in the international system and particularly in its current particular conditions, Russia tries to increase its relative power and it can resort to war and force for achieving this goal. Attack on Ukraine and its offensive policies in this region in 2014 are an indication of this fact and an evidence for this claim.

\section{The Bases of Putin's Foreign Policy}

Since the end of the $70^{\text {th }}$ century, the proponents of the Normalized Modern Great Power and at the head of them, Vladimir Putin, as the main critic of Primakov's foreign policy, which, according to Putin, was too ambitious, ideological, confrontational and anti-Western, appeared in the political arena of Russia. Paying serious attention to the need for adaptability in the field of foreign policies, Putin put three fundamental goals as the basis for his foreign policy including economic modernization, achieving an proper position in the process of global competition and restoration of Russia's position in the international system as a great power. Taking a pragmatic approach, which was based on Russia's hardware and software capabilities considering the requirements, Putin put in a great deal of effort to operationalizing these goals (Trenin, 2004). As Russia lagged behind in many aspects including economic, political and military fields, Russian politicians sought to rebuild their domestic and foreign policies. After the collapse of the Soviet Union, the main focus of Russia's domestic and foreign policies has been on reviving the economy of their country and also fighting against America's unilateralism and restoring its lost power and authenticity (Olikier, 2009, 38). Therefore, after Putin's accession to power, the most important components of Russian foreign policy were centered around establishment and 
improvement of Russia's reputation and authority. For achieving this goal, a change from and passing from Atlantic Orientation to Eurasian Orientation seemed to be a smooth and the most logical path to the Russian politicians of the time. In addition to this change in the discourse, the bad economic conditions and also bypassing the law were other issues that influenced the setting of priorities and the bases of Russia's foreign policy during Putin's rule and became one of the basic necessities of Russian foreign policy during this period.

At the end of the communist era, the Soviet Union politicians, who saw the danger of their collapse tried to make certain reforms to save themselves from falling in the abyss of disintegration. These reforms included Glasnost and Perestroika's plans which were not found to be effective. After the collapse of the Soviet Union and the rise of the new system, an attempt was made to follow moderate policies in the political arena and the relations with the West and in the economic area, there was an attempt to protect and preserve the position of this country as a first-class power. But taking these policies during the presidency of Yeltsin led to the lowering of the position of Russia in the global arena. The end of Yeltsin's rule and Vladimir Putin's admission to power was a beginning for basic changes in the policies of this country particularly in the international arena and its foreign policies. Putin sought to rebuild and increase Russia's power in the international arena (Mancevic, 2006, 6).

To summarize, the basis of Russian foreign policy during this period had the following features:

- The dominance of a combination of Slavic Orientation and Eurasian Orientation over Russia's foreign policy system,

- Redefinition of the identity of this country at the international level,

- Economic modernization and advancement of Russia's economic interests in the framework of adaptation with the international system,

- Achieving a proper position in the process of global competition,

- Rebuilding Russia's position of authority as a "great power",

- Taking a pragmatic approach in the framework of the Normalized Great Power theory.

The soft balance between Russia and the United States following the collapse of the Soviet Union and the bipolar international system, was supported based on Russia's regional strategy in the geopolitical area of "the near abroad". At the end of 1992, this country adapted its strategy based on the idea of controlling the regional countries. Hansen believes that during this period Russia made some attempts to recover its influence and authority in the bordering areas. It was against the development of the great powers in these strategically important regions. According to the prominent officials of this country including Putin, the countries and lands neighboring with the Russian federation have had a special significance for Russia since old times for security, cultural and economic reasons (Khatami, 2004, 27). With Putin being put at the top of the political power pyramid in Russia, for the first time the foreign policy of this country was shaped and established in its real form (Afshordi, 2002, 276). For this purpose, Russia first turned its attention to the regional countries, the region referred to as "the near abroad" in its political literature and this country considers this area as its backyard (Dadak, 2010, 90). The presence of a third player, i.e., America in this region and, consequently, threatening of the political, economic and security interests of Russia has led this country to have particular view of the South Caucasus and to try to decrease the opponent's influence and authority in this region (Shafee, 2010, 24). Competition over the energy resources and its transfer routes, security dependence of the regional countries on Russia or America, the conflicting blockings of the powers, the attempts to eliminate or weaken other regional actors such as Iran and Turkey and militarization of the region under the shadow of Georgia's conflict with Russia and also the Karabakh conflict has caused the competitive atmosphere to be sustained so that none of the two opponents is able to win absolute dominance over the region.

\section{Russia's Foreign Policy during Putin's Presidency}

During Putin's presidency, Russia adopted an offensive approach in its foreign policy with the aim of reviving its old place in the international system. In line with this purpose, Putin initially prepared and developed the theoretical background for this new approach in the framework of four documents in 1999-2000, which was generally referred to as Putin's doctrine. But in early years of the third millennium, certain motives such as the color revolutions and America's offensive policies towards Russia, and also Putin's success in Russia's internal affairs, America's failure in Iraq and Afghanistan and Russia's increased economic capabilities helped to implement the policies intended and aimed by Putin and led to increasing militarism and diplomatic expansionism of Russia (Talebi Arani, 2007, 1). 
In Putin's time, Russia has been influenced more than anything else by international evolutions such as globalization in all its aspects, the process of integration or convergence in Europe, America's expansionism, growth of Islam, international terrorism, energy security, the increasing power of China and India and the developments and changes in the international economy. The pragmatic approach taken by Putin in foreign policy was focused upon certain principles such as emphasis on action, positive play and confrontation in foreign policy. From the beginning of his rise to power, Putin based his policies on three major goals including economic modernization, achieving an proper position in the process of global competition, and restoration of Russia's position in the international system as a new great power. And for achieving these goals, he proposed "The Normalized Modern Great Power" theory, in which visionary democratic nationalism plays a pivotal role, as the new strategy in his foreign policy (MosallaNejad, 2013, 122).

Following an offensive policy in the field of energy, emphasis on establishing its power as an "energy superpower" in the New Middle East policies, following the costly military modernization programs and the sale of military equipment, opposition to the deployment of a missile defense shield by America in Eastern Europe and, consequently, suspension of Conventional Arms Treaty, establishing new anti-missile defense bases in San Petersburg and the unexpected announcement that it has pointed its nuclear missiles towards Europe, and resistance against America and the European Union for declaration of independence for Kosovo are among the main issues in this period which Russia tries to remind its foreign counterparts particularly the West of its promoted position in the international arena concentrating actively on these issues and propose itself as a great trans-regional power in the regional arrangements and equations (Baylis, 2005, 32). Putin's accession to power is considered as a milestone in the domestic and international policies of this country after the Cold War. On the one hand, Putin has tried to resolve internal crises and return stability and solidarity to Russia and, on the other hand, stand against the constraints provided mainly by the West and their expansionism against Russia by bringing it out of its shell using a progressive and offensive approach. By this, Putin aimed at returning and restoring the old reputation to Russia and recover it as a great world power. For this end, it can be stated that Putin's offensive approach in foreign policy was a reaction against the Yeltsin's submissive attitude towards the West and particularly America. Therefore, by pursuing the Eurasian Orientation policy, Putin not only stood against America's unilateralism but was able to play the role of an empire in the Caucasus and Eurasia regions. He also had a new look at the Asian countries trying to establish its position in the region and certain behaviors were shown by Russia, which are indicative of this fact. Some of these behaviors include:

- Making a visit to North Korea and Cuba,

- Abolition of the Gore-Chernomyrdin Treaty,

- Forming a coalition with China to for confronting America's unilateralism and the creation of the Shanghai Cooperation Organization and making Iran an observer member of this organization in 2004,

- Meeting with great powers such as America as a prudent and pragmatic strategy,

- Paying attention to the region and the commonwealth countries,

- Vladimir Putin strongly and authoritatively supported and sought the revival of the role of Russia in the international arena and looks at Syria as its last base in the Middle East. With a review of the history of the friendship of these two countries and the old relationship between Russia and the Syrian Ba'ath Party, the importance of Syria's port of Tartus and the academic relations between the two countries can be considered as evidence for and indicative of this friendship.

- Russia's defense of Iran's nuclear rights.

Another area of conflict between Moscow and Washington in 2009, which also devoted a part of the energy of the Russian diplomacy system to itself, was the issue of Iran's nuclear program. Despite the fact that following the relative improvements in the relations between Moscow and Washington, in some sources a reference was made to their deal over Iran and Medvedev's and other Crimean officials' emphasis on the possibility of Moscow's agreement and compliment with the policy of imposing sanctions against Tehran in the case of failure in reaching a solution and conclusion from other ways led to further speculations about this possibility, but Moscow could keep its Russia's interests in Tehran and Washington in 2009 with its diplomatic skills (Noori, 2009).

The formation of regional organizations such as the Commonwealth of Independent States (CIS) Union, the strategic position and the rich energy resources in the region has made the regional and global powers particularly the United States pay a particular attention to this region (Naumkin, 2002, 31). The entrance of these powers and especially America into this area has led Russia to more carefully follow and observe the changes in the region, which is referred to as "the near abroad" in Russia. 
As a symbol of authoritarianism in Russia, Putin acted differently from the traditionalist leaders of the authoritarian systems in the undeveloped countries in reaction to the emerging political and social events in his country. Gaining power using completely democratic processes during the years from 2000 to 2012, withdrawal from presidency in the 2007 presidential elections, helping to create new political and economic democratic institutions during his presidency and allowing the opponents to participate in the two elections, i.e., presidential and parliamentary elections and, finally, showing a constructive and favorable reaction to the urban demonstrations of the opposition groups are considered as evidence for Putin's commitment to the principles of political development. In addition, by writing a very important article entitled "Democracy and the Quality of Government", which was published in February 2012 in the Kommersant newspaper, Putin declared his absolute commitment to political development and strengthening of the civil society as current requirements of Russia and announced some of his plans for satisfying these requirements.

The most important obstacles facing Putin for the realization of political development include:

- concern about the interference of foreign agents in Russia's internal affairs,

- the dependence of Putin and his followers on the economy of oil and gas,

- the likely turning away of some parts of Putin's social support base during his future presidency,

- the looming economic crises in Russia and the West and the concern of the middle class about the undesirable effects of these crises on political and economic development in Russia,

- the growing unresolved crises in Russia in underdeveloped regions of North Caucasus and the Far East,

- the growing national chauvinism among the Russians (Shargh Newspaper, 2012, 7).

Although the assumption of homogeneity of Putin's foreign policy during the eight years of his presidency is questionable, in the same line with the analysts this policy can be divided into different periods from different perspectives. Furthermore, although at some points Putin's foreign policy has been diverted from his pragmatic principles under the influence of the high sensitivity of the geopolitical and identity issues such as tension with Estonia about the Monument of the Unknown Soldier, Moscow-Kiev strong confrontation in the case of the possibility of Ukraine's membership in NATO, tensions with Washington about America's missile defense shield and diplomatic arguments with London in the case of the death of Alexander Litvinenko, a brief review of Russia's general behavior in the field of foreign policies during Putin's government reveals that he is practically committed to the principles of pragmatic approach (Koulayi, 2010, 213). Despite the Crimean policy-makers' attempt to recognize and introduce Russia as a normalized great power in the international system, he was considered by majority of the world countries as an abnormal or non-normalized agent in the international system for his positions during the Ukraine-Moscow crisis and this is the result of radicalization of the Eurasian Orientation policy. As long as the stance on Eurasian Orientation was moderate and softened and with an emphasis on a pragmatic behavior, Russia had been able to introduce itself as a normalized agent in the international system to a certain extent.

\section{The Offensive Aspects of Putin's Policies}

Putin's doctrine in 1999 is the beginning of a new period in the foreign policy of Russia. After developing and formulating this doctrine, the September $11^{\text {th }}$ events took place which resulted in an increased unilateral actions by America. Following these unilateral actions by America, Russia also took an offensive approach in practice. But in addition to this factor, i.e., America's unilateralism, there were other pre-existing factors which caused this to happen and played a very significant role in the development of Putin's new doctrine. For instance, such issues as the expansion of NATO to the East, formation of color revolutions in the independent states of the former Soviet Union, America's growing military presence in Central Asia and Caucasus, America's interference in Russia's internal affairs, excluding Russia from participation in international decision-makings and determining the agenda led the focus and behavior of Russia's foreign policy change and be impregnated with militarism, weapons, threatening and invasion.

The most important issues in Russia's foreign policy during Putin's run include the following:

- Increased Militarism: The manifestations of this situation can be seen in Russia's plans for increasing the number of its conventional weapons and missile arsenals, improving the quality of Russian weapons, lack of interest in membership in military and security commitment unions, which create limitations for Russia in confronting America, and the attempt to withdraw from and get out of military pacts and commitments. These aspects of Russia's offensive policy are particularly concerned with the United States. The battlefield for these two countries during the last two years has not been limited to Eastern Europe but expanded to the Atlantics. 
- The Use of Weapons as a Means of Putting Pressure: This aspect of Russia's offensive foreign policy is mainly related to and directed at the European countries. But in addition to the European countries, some of the neighboring countries such as Ukraine, which wants to follow policies that are against Russia's security, are also the target of this policy. Using its huge gas reserves, as the sole supplier of gas to Europe, Russia attempts to use this economic weapon as a means of putting pressure in its foreign policy. An evidence for this is the time when Russia threatened Ukraine in 2014 that Russia would cut gas imports if it did not pay its deferred debt.

\section{The Opportunities and the Substrata of Russia's Eurasian Orientation Policy during Putin's Run}

After the collapse of the former Soviet Union and especially Yeltsin's submissive policies and worsening of the economic conditions, Russia sought to redefine and its authoritarian identity in the international arena. Under the conditions, following the increase in the price of energy resources and having the monopoly of energy resources and also with the dependence of other countries on Russia, this country got a new life and thanks to the improving economic conditions, it tried to restore its international reputation. In this case, only one enemy can confirm the identity and authority of a country. Therefore, Russia claimed that only America could come to grips with Russia. From this perspective, taking the Eurasian policy with an offensive behavior has different effects on Russia and its status in the field of international relations and at the regional level some of which will be mentioned in this section.

\subsection{At the Internal Level}

It may seem that the choice of Eurasian Orientation policy with an offensive taste has no role in Russia's internal affairs, but the selection of this policy and its effects on the internal developments are important in some respects. When Putin came to power, the only thing he inherited from the previous period was bad economic conditions and social dissatisfaction. Accordingly, the lucky simultaneity of Putin's policies with the rise of energy price led to his economic and political success. As a consequence, the trust and confidence achieved by the improving conditions of the country and Russia's offensive foreign policies, on the other hand, has promoted Putin's position as a national hero as the symbol of a modern and powerful Russia and getting Russia out of the mire of problems and establishing its position in the international arena became the major strategic goal of the charismatic character of Putin.

In addition, Russia's offensive stance in the international arena has led to internal solidarity and unity and Russia's attention has shifted from 'following' and Atlanticism to Eurasian Orientation. It can be claimed that Russia's identity issue has been resolved as the result of the Eurasian Orientation. Therefore, it seems that Russia's offensive policy and Eurasian Orientation policy are directly related.

\subsection{At the Regional Level}

At the regional level, Eurasian Orientation policy has a positive and a negative view. Based on the positive view, Russia can justify its interferences in some of the policies of the regional countries that are related to America in the framework of its confrontation with this country. But, on the other hand, this can have negative consequences such that some of the regional countries may feel insecure due to Russia's offensive policy in their affairs. In this way, some conflicts may arise at the regional level.

\subsection{At the Level of International System}

The new policy adopted by Russia based on Eurasian Orientation and in the framework of the offensive realism theory, which originates from Putin's doctrine and has anti-American symbols, has had different effects on Russia's reputation in the international scene.

First, this policy posed a challenge to the unipolar system and America-centrism and has introduced Russia as a strong barrier against America. Such a claim is made in the multipolar system theory.

Second, the existence of such a phenomenon reveals the fact that America's power is not eternal and the appearance of another polar may challenge the nature of hegemony.

Third, challenging America at the international level has made Russia important in the region and, in fact, for those opposed to America, Russia is the hero and their supporter in the international decision-makings. This attitude has also posed a challenge to the order desired by the United States in the sensitive and critical regions.

\section{Eurasian Orientation: The Motive for a New Cold War}

The collapse of the Soviet Union was a significant milestone in changing the dominant pattern of the international system, and consequently, changing the dominant attitude in Russia's foreign policy. Although at the beginning of the collapse of the Soviet Union, the prevailing view was to follow the hegemony and Russia 
considered friendship with America and following Washington as its nature and identity, but when Putin got into power, the pragmatic policy of Putin and, subsequently, all attentions were directed at Eurasian Orientation and the self-confidence created by the improving economic conditions and the rising energy price convinced Russia to redefine itself and not only to avoid following the hegemony but oppose it and restore the role and identity of the original Russia to the land broken into pieces. With such as view and the presence of theoreticians such as Dugin, Russia's major concern was to define and determine certain policies and perspectives based on Eurasianism and its view of the region. Therefore, after Russia became relatively powerful and following the improved conditions in this country, its offensive policies expanded in the regional and at the international level.

There are two different views about the change of the competition between America and Russia into the Cold War:

- According to one view, the competition between Russia and America will not turn into another cold war. The reasons provided for this claim are the signs of the relationship between the two countries after the Cold War; their post-war relations has gone through a process that is indicative of cooperation and interaction rather than confrontation and competition despite the ups and downs. This cold-war approach to the relations between America and Russia pays little attention to some of the global trends requiring the development of regional cooperation, the need for a dynamic interaction in the process of world economy and also the dominance and development of liberal democracy values. Finally, it can be stated that the improved internal conditions and the rising price of the energy resources created a self-confidence in Russian leaders for more serious confrontation with the anti-Russia provocations in Caucasus. Extensive military intervention by Russia in Southern Eurasia is not only indicative of Russia's geopolitical reappearance in Caucasus but also a deterrent strategy and a serious warning and threat to the regional countries to reconsider their anti-Russian attitudes (Ebrahimi and Mohammadi, 2011, 17).

- However, with the emerging developments and changes in Ukraine and Crimea's secession to Russia and America's and Russia's interferences in the region supported the view that another cold war is happening. The differences and conflicts between Russia and Ukraine had a great impact upon the social status of the country members of the Commonwealth of Independent States (CIS). Ukraine has the largest population and the highest economic and political capacity in CIS after Russia. Accordingly, it has always attracted the attention of Russia, on the one hand, and the West, on the other. A part of their conflicts and differences is concerned with determining the status of the Crimean peninsula. This peninsula, which was separated from Russia and attached to Ukraine during Khrushchev's run, has a special position and significance in the Black Sea. The largest Soviet Navy is at the Port of Sevastopol at the coast of the Black Sea. Furthermore, another aspect of the differences and conflicts between the two countries is motivated by economic issues. Ukraine claims to have a share in the Soviet assets abroad, which Russians have taken over with the excuse that they are the legal successor to the Soviet.

The relations between Russia and America in the last years of Putin's presidency had a particular quality. In this period, taking an offensive pragmatist approach, Putin adopted the policy of "Direct Resistance" against the expansionism of the West and, particularly, America imperceptibly from 2006 and obviously from the beginning of 2007 considering the self-confidence he had built up by the achievements and successes in the political and military fields and particularly the unexpected inflow of dollars from oil resources into the Russian economy. The point of departure for this trend, which Derek Averre refers to as Putin's Munich doctrine, was his speech in Munich Security Conference in which he severely criticized America's unilateral approach (Koulayi, 2007, 213).

Russia is the heart of the Soviet Union and many of the social and structural features of the Soviet can be seen in the political and strategic foundations and components of this country. Its competition with the United States goes back to the $19^{\text {th }}$ century. These competitions were initially formed in the framework of balance of power in the international policies. America and the Soviet Union formed the bipolar international system from 1945 to 1991 and, currently, after the collapse of the former Soviet Union and the end of the bipolar international system, Russia has been still following the strategic policies of those times and claims to be fighting with the unipolar system. The most important areas of conflict between Russia and America are the security issues. Russia is totally opposed to the development of NATO and the growing unilateralism being followed by the United States and always shows reactions to them. The examples of this strategy and approach can be observed in its disagreement with America's missile defense plan and criticism of America's strategic policy and intention to withdraw from the Anti-Ballistic Missile Treaty (Koulayi, 2007).

Russian politicians believe that great powers need great enemies. A superpower needs another superpower that stands against it. The more powerful and the greater the enemy is, naturally the more glorious it will be to stand 
against it. Therefore, it is only America which has the competence and capability to be an enemy to the United States. Russia needs a totally new identity that can replace the identity and ideology of the time of the Soviet Union. With this new identity, Russia can determine its position in the world and among the great powers. This country is defining itself in a new promised land. The Western model, which had been considered as a desirable pattern for Russia at the beginning of Yeltsin's run, has faded into insignificance both from the Russian people's and politicians' perspective. The Missile Defense Shield raised some points with regard to the future and prospect of the relations between Russia and America for the macro-level analysis. He first referred to the existence of two trends of thought in Russia, i.e., Atlanticism (West-orientation) and Eurasianism. There are both extremist and moderate groups within each thought trend.

The West's sanctions, which seemed totally inefficient at the beginning, is now having a very negative effect on Russia's economy. Above all, the significant decline in oil prices over the past few months, has greatly affected Russia leading to a sharp drop in its export earnings and the value of Ruble. Eastern Ukraine has also turned into a dangerous region for Russia at the present time due to the killing of Russian soldiers involved in war. In the same way, the West's disagreement with and even fear of Russia has increased and European economic and political leaders have become less inclined to makes investments in Russia and help Moscow and cooperate with Putin (Katz, 2014). The Ukraine crisis can also become an excuse for intensive geopolitical competition between America and Russia all over the world, but the commonalities such as moderated nuclear weapons can increase the areas of cooperation between the two countries. Otherwise, if this competition is not moderated, it can lead to a significant hidden competition in international relations, which influence many other issues.

Today, half of the Russian population believes that if we put aside and ignore Russia's frustration in Afghanistan, during the former Soviet Union, the international conditions have been more stable, reliable and in favor of and to the advantage of Russia. Only $5 \%$ of the Russian people believe Russia had a good position in the international arena during Yeltsin's rule. Russia needs a foreign enemy in order to find and determine its direction. When Putin refers to enemy, the Russian people realize that, if he does not mention the name of this enemy, he is referring to the United States, which dropped with anger the first nuclear bomb on Hiroshima, destroyed Vietnam with different types of poison and, more importantly, has put in all its efforts to destroy the glory of their native land, i.e., Russia. Russian people, however, like Europe in contrast with the United States. According to the Russian people, Europe is a praiseworthy entity that nobody is definitely afraid of. $80 \%$ of the Russians believe in the existence of positive and warm feelings between the Europeans and the Europe. Nevertheless, Russians still credit their Asian origin. 50\% of the Russians do not consider themselves as European and believe that Russia has never been European. This group of Russian people are proud of Russian traditions and values. Europe and, particularly, European countries are too small, in the Russians' eyes, to count as an enemy and play the role of an enemy (Der Stürmer, 2011, 291).

Considering the conflict with the West over the establishment of missile defense shield and with the end of the period of building trust between the two countries, Put wanted the West to reform its wrong behavior at the peak of distrust between the two countries under "Moderate Eurasian Orientation" despite the fact that he believed in creating a balance between their view of and relations with the East the West. The relations with America has always had ups and downs in Russia. However, these relations can be divided into two periods: the first period started from the collapse of the Soviet Union and continued until September 11 $1^{\text {th }}, 2001$ and the second period started with the attack on the twin towers of the World Trade and has continued up to now. In the first period, the ideological competition between the two countries had ended due to the collapse of the Soviet Union and security policies and America's military doctrine, which was founded upon opposition to and inhibition of communism, was intrigued by strategic confusions and ambiguities, but America still views itself superior to Russia considering the new unipolar structures. In the second period, Putin's accession to power and the September $11^{\text {th }}$ events were two important factors that made the relations between America and the Russian Federation step into a new stage.

Putin had improved the undesirable conditions in Russia to a large extent. On the one hand, he showed a cooperative orientation towards fighting terrorism and, on the other hand, exercised power within the country. But, overall, none of the players could ignore the other side. Thus, the competition for gaining more benefits and interests continued (Ebrahimi \& Mohammadi, 2011, 8).

Generally, the measures taken by Russia in its new confrontation with America and NATO include the following:

- The massive sale of weapons to the countries challenging America and Europe,

- Carrying out a 200-billion project for empowering the Russian army, 
- An attempt to establish the rule of Russia over some regions of the North Pole,

- The resumption of flights of strategic bombers in distant areas,

- The suspension of Russia's membership in the treaty on Conventional Armed Forces in Europe,

- Expulsion of English diplomats from Russia,

- Testing new ballistic missiles,

- Suspension of cooperation with NATO until further notice (Ebrahimi \& Mohammadi, 2011, 16).

Activation of Russian diplomacy in the Middle East, encouraging the Middle East governments to have security cooperation within the region in the framework of Shanghai Organization instead of the models of mutual military-security agreements with America and measuring its success, turning the Western (under the leadership of America) and Eastern (by facilitating a coordination between China and Russia) conflict into an identity conflict, and Putin's clear disagreement over NATO's unilateral actions under the leadership of America for solving the crises in Europe and particularly in Eastern Europe and the Balkans are all examples of these measures. Despite that, it seems that the world is passing and moving to a new plan of polarization.

Russia's worry about its primary security circuit increased with the West's and particularly NATO's increasing presence after the September $11^{\text {th }}$ events. America's intrusion into the traditional area of influence of Russia in the middle of the 1990s caused a threat to the Russian interests, but the peak of this progressive movement by America was after the September $11^{\text {th }}$ events. After these events, the United States had direct presence in the region deploying its forces to the bases in the regional countries. At this time, Russians showed a passive reaction watching the growing presence of the Americans in the Caucasus and the Central Area and were not very pessimistic about this presence. After the initial shock of the initial horrific events subsided and America's strategic goals for having presence and establishing military bases and also creating and fomenting color revolutions in the Central Asia countries and Caucasus as a direct result of the issues were revealed, Russians felt an looming threat and their way of interaction with America greatly changed. They used different strategies as a lever to challenge this country's (i.e., America's) desired order in the region and drive and force America away from their geostrategic area. Among the strategies and reactions shown by Russians were their absolute rejection of America's plan to operate a missile shield in Eastern Europe, considering the preparation and establishment of new nuclear missile sites in Petersburg and announcing the use of the fleet of long-range nuclear patrol aircraft. These measures reached their peak by establishing the Shanghai Treaty Organization. Shanghai Treaty was the result of America's encroachment upon Russia's and China's geopolitical area bringing these two countries together (MojtahedZadeh and RashidiNejad, 2011, 14). In fact, Russia's foreign policy in the Middle East as a country that claims to be reviving its lost power in the international arena can be evaluated and examined with respect to this claim and in terms of its position towards the war in Afghanistan and Iraq, the nuclear issue of the Islamic Republic of Iran, Syria, Palestine and the countries experiencing Islamic awakening.

On the whole, Russia has always been opposed to America's presence in the Middle East both overtly and covertly. This opposition has been much stronger particularly when this presence has been along with military operation or has not been approved and supported by the United Nations. Russia was opposed to America's attack on Iraq from the very beginning such that some experts talked about the likely veto of this plan by Russia in the Security Council before America started the attack.

Russia's measures were, in fact, also the beginning for a new polarization after the Cold War. In line with that, an opposing power is emerging and developing against a power that seeks to establish a hegemonic order. The anti-hegemony power is being formed with Russia's initiative. Although Russia is not as powerful as America, the polarization trend against America can, at least, create a challenge for the power of America (Talebi Arani, 2007, 23).

Based on the mentioned principles, Putin believed in lack of confrontation and gaining advantage until the threshold of tolerance topples. An evidence for this is Russia's support for the war in Afghanistan, the initial not-so-serious oppositions to the war in Iraq and lack of serious disagreement and opposition to the military cooperation between America and Georgia (Harutyunyan, 2007, 11). By replacing the concept of "multilateralism" with the concept of "multipolar system", Putin made an attempt to replace the components of competition and tension in the idea of multipolar system with the components of competition and cooperation in the concept of multilateralism. In the concept of multilateralism, Russia defined a positive role for itself in the cooperation with the West and even America and considered itself as an international strategic arrangements partner particularly in the security issues (Koulayi, 2010, 217-219). Taking the Eurasian Orientation policy by Russia and standing against America instead of following and complying with it, has had different effects on 
Russia and its status in the area of international relations and at different regional levels. In addition, at the internal level it led to gaining trust and the promotion of the position of Putin inside Russia and introduced him as a national hero and the symbol of powerful and modern Russia and saving Russia from the mire of problems and establishing its position in the international system became a major strategic goal. Furthermore, Russia offensive stances in the international arena has created internal solidarity and with the change of Russia's policy from 'following' and Atlanticism to Eurasian Orientation has helped to resolve Russia's identity issues to some extent. Therefore, it seems that offensive policy and the Eurasian Orientation are directly related.

There is also a positive and a negative view of the Eurasian Orientation policy at the regional level. According to the positive view, Russia can justify some of its interferences in some of the policies of the regional countries that are related to America and justify them in the framework of its confrontation with America. But, on the other hand, this can have negative consequences such that some of the regional countries feel insecure due to Russia's interferences in their affairs which, accordingly, can cause some conflicts at the regional level leading to the weakening and decline of Russia.

However, the new policy taken by Russia, i.e., Eurasian Orientation, in the framework of the offensive realism theory, which originates from Putin's doctrine and has anti-American symbols, has had different consequences for Russia's reputation in the international arena. First, this policy challenged the unipolar system and America-centeredness and introduced Russia as a powerful player against America. This claim is raised in framework of the multipolar system theory. Second, the existence of such a phenomenon is indicative of the fact that America is not an eternal great power and the appearance of another polar may challenge the nature of hegemony. Third, challenging America at the international level is the cause of importance of Russia in the region and, in fact, from the perspective of the enemies of America, Russia is their hero and supporter in the international decision-makings. This attitude has also posed a challenge to the order desired by the United States in the sensitive and critical regions.

In addition to the regional countries, Russia considers the presence and enmity of any other power as an obstacle and threat to its security and interests. As a result, fighting America and preventing the development of NATO in the region originates from Russia Eurasian Orientation and, consequently, indicative of its offensive approach that tries to nip any feeling of insecurity in the bud. The collapse of the Soviet Union, in fact, changed the conditions in the international system making America a hegemony that rules over the world and spares no effort to keep and preserve the status quo. In contrast, Russia is still thinking of realizing its old dream, i.e., gaining control over the whole world or at least, at the present time, domination and control over Europe and Asia. Therefore, it is not content with the existing situation can use the domino of attaching the regional countries such as Crimea to Russia to realize this dream.

\section{Conclusion}

Russian politicians believe that great powers need great enemies. A superpower needs another superpower in front of and against it. The stronger and the more powerful the enemy is, the more glorious it will be to stand against it naturally. Therefore, it is only America which has the capability to be an enemy to Russia. Russia needs a totally new identity that can replace the identity and ideology of the Soviet time. Accordingly, following the inefficiency of Russia's 'following' and submissive policy during Yeltsin's run and worsening of the economic conditions during this period, Putin appeared as the savior of Russia and got into power.

Adoption of the Eurasian Orientation policy by Putin not only led to Russia's domination over Europe and Asia but could improve the economic conditions of this country. By creating unions including the CIS Union, Putin could bring the independent states of the former Soviet Union close together and also have control over the economic and political conditions in these countries. Russia's attempt to prevent the membership of the regional countries in NATO is an example of Russia's interference in the region in the framework of its Eurasian Orientation policy.

Reinforcement of the Commonwealth of Independent States is one of the priorities in Russia's foreign policy after Putin's accession to power in line with his Eurasian Orientation policy. This community aims at the convergence and unity of the Eurasia region. In contrast with it is the Guam Union, which tries to diverge rather than converge the Eurasia region and particularly fight against Russia's domination in the region and has an inclination towards the entrance of trans-regional powers such as America into the region and membership in NATO. Despite the establishment of the CIS Union as a great union, we see the formation of smaller unions such as the Guam Union at the heart of this great union. These countries, i.e., members of these small unions, bring the bad memories of the Soviet time into their mind and are worried and fear that Russia might be a threat to 
their sovereignty and independence. Thus, by turning to America they try to dampen or dissipate the offensive policies and domination of Russia.

The United States of America is the greatest challenge to Russia at the international level. On the other hand, the CIS countries' worry about and fear of the domination of Russia over them is one of the most important challenges and obstacles to advancing the Eurasian Orientation policy by this country. On the whole, the most important effect of the Eurasian Orientation discourse on the behavior of Russia is that as the Eurasian Orientation policy becomes more prominent in Russia's foreign policy, its foreign policy becomes more offensive leading to the isolation of Russia in the international arena. Accordingly, one of the most important strategies to be taken by Russia is to follow Moderate Eurasian Orientation. Therefore, although Eurasian Orientation plays the role of a moderator and can lead to the empowerment of Russia, if it moves away from moderation and towards extremism, it will not only bring no power for this country over time but also lead to its isolation in the international arena.

\section{References}

Afshordi, M. H. (2002). The Geopolitics of Caucasus and the Foreign Policy of the Islamic Republic of Iran. Dore-ye-Aali-e-Jang Publications, The School of Command and General Staff, Tehran.

Bailes, A. J. K. (2005). The European Security Strategy: An Evolutionary History. SIPRI Policy Paper 10. Stockholm: Stockholm Peace Research Institute.

Browning, C. (2008). Reassessing Putin's Project: Reflections on IR Theory and the West. Problems of Post-Communism, 55(5), 3-13.

Dadak, C. (2010). A New Cold War? The Independent Review, 15(1), 89-107.

Der Stürmer, M. (2011). Russia in Putin's era of limited confrontation and the emergence of Russia (1st Ed.). In A. A. Abdurrashidi (Trans.). Soroush Publications: Tehran.

Dougherty, J., \& Pfaltzgraff, R. (1993). Contending Theories of International Relations: A Comprehensive Survey. In V. Bozorgi, \& A. Tayyeb (Eds.). Qumis Publications: Tehran.

Ebrahimi, S., \& Mohammadi, M. (2011). The competition between Russia and America in Southern Caucasus (1991-2010). Central Asia and Caucasus Studies Quarterly, 4(8), 1-22.

Harutyunyan, G. (2007). A Multi-polar Cold War. 21-st century, 1, 6-13.

Hopf, T. (2009). Russia's Place in the World. PONARS Eurasia Policy Memo No. 79 the Ohio State University. 19.

Katz, M. N. (2014). Will Putin Lash Out? Retrieved from http://www.lobelog.com/will-putin-lash-out/.

Khatami, K., \& Shahi, S. E. (2004). Commonwealth of Independent States. Abrar-e-Moaser Publications: Tehran.

Koulayi, E. (2011). Policy and government in Central Asia. Samt Publications: Tehran.

Koulayi, E., \& Nouri, A. (2010). Putin's pragmatism: a strategic development in the foreign policy of Russia. Siasat Quarterly, 40(2), 209-228.

Makarychev, A. S. (2008). Politics, the State and De-Politicization; Putin's Project Reassessed. Problems of Post-Communism, 55(5), 62-71.

Mancevic, D. (2006). The Russians are coming. Russian Foreign Economic Policy to Ex-Soviet States- the cases of Georgia and Ukraine. Retrieved from http:// www.idec.gr/iier

Mearshiemer, J. (2001). The Tragedy of Great Power Politics. New York: Norton Company.

MosallaNejad, A. (2013). The strategic balance and security policy-makings of Russia in the international system. Journal of Mota-le'at-e-Eurasia-ye-Markazi (Central Eurasia Studies), 6, 121-140.

MoshirZadeh, H. (2010). A development in the international relations theories (5th Ed.). Samt Publications: Tehran.

Naumkin, V. (2002). Russian Policy in the South Caucasus. The Quarterly Journal, 1(3), 31-37.

News-analytics website of Fararu. (2014). Is the new Cold War like this? Retrieved from http://fararu.com/fa/ news/189298

Nouri, A. (2009). Russia's foreign policy during Putin's period: principles and trends. University of Imam Sadigh: Tehran. 
Oliker, O., Crane, K., Schwartz, L. H. \& Yusupov, C. (2009). Russian Foreign Policy, Sources and Implications. Santa Monica: Rand Corporation.

Primakov, Y. (2012). The World without Russia. Translated by Iras: Tehran.

Salimi, H. (2005). Virtual government or offensive realism: A comparative analysis of Richard Rovez Créancey and John Mearsheimer's theory. Journal of Hoghugh-va-Siasat (Law and Politics), 7(17), Autumn and Winter.

Schweller, R. L. (1996). Neorealism Status Quo Bais: What Security Dilemma. Security Studies, 5(3), 90-121.

Shafee, F. (2010). New Geopolitics of the South Caucasus. Caucasian Review of International. Affairs, 4(2), 184186.

Shargh Newspaper. (2013). Alexander Dugin, a Post-liberal Fundamentalist, 1750, 7. Roundtable Discussion of Shargh.

Sherafat, S. (2004). International control of the Weaponry, Russia's security-oriented view in CIS countries (pp. 121-170). In E. Khatami Khosroshahi (Ed.). Studies and Research Institute of Abrar-e Moaser.

Steve, S., \& Baylis, J. (2002). Globalization of World Politics. In Goruh-e-Motarjemin (Trans.). Abrar-e-Mo'aser Publications: Tehran.

Talebi Arani, R. (2007). An analysis of Russia's offensive foreign policy against America. Department of Political Studies, Foreign Policy Group.

Trenin, D. (2004). New Tendencies in Russia's Foreign Policy. Carnegie Endowment for International Peace.

\section{Copyrights}

Copyright for this article is retained by the author(s), with first publication rights granted to the journal.

This is an open-access article distributed under the terms and conditions of the Creative Commons Attribution license (http://creativecommons.org/licenses/by/4.0/). 